\title{
George L. Cowgill, December 19, 1929-July 31, 2018
}

\author{
Michael E. Smith, ${ }^{a}$ Oralia Cabrera Cortés, ${ }^{a}$ Karen D. Cowgill, ${ }^{b}$ Keith W. Kintigh, ${ }^{a}$ Deborah L. Nichols, ${ }^{c}$ \\ Ian G. Robertson, and Barbara L. Stark ${ }^{\mathrm{a}}$ \\ aSchool of Human Evolution and Social Change, Arizona State University, Tempe, Arizona \\ bepartment of Global Health, University of Washington, Seattle, Washington \\ 'Department of Anthropology, Dartmouth College, Hanover, New Hamspshire
}

\begin{abstract}
George L. Cowgill had a major influence on the study of the ancient city of Teotihuacan and the development and promotion of quantitative methods in archaeology. His wit, teaching, and research influenced many in the profession. We draw on two published autobiographical works (Cowgill 2008a, 2013a), some unpublished autobiographical notes (Cowgill 1983), his many publications, and our own associations with George.
\end{abstract}

\section{BIOGRAPHY}

George Lewis Cowgill (the first syllable rhymes with "know," not with "how") was born on a December day in 1929 in a drafty farmhouse just outside Grangeville, Idaho, on the site of what is now an RV resort. He was the second twin, a surprise; the first twin was Warren Crawford Cowgill, who became a noted linguist (Figure 1). George was born in what he described (Cowgill 1983) as "the wheat, barley, peas, cattle, sheep, timber, and some mining reaches of northern Idaho, in an area of sparse population and small towns, remote from any cities." This was the Camas Prairie, just above White Bird Canyon, where the Nez Perce Indians defeated the United States Army in the Battle of White Bird Canyon in 1877.

George and his brother Warren had no other siblings. As preschoolers they communicated with each other in a type of twin talk they called Fuadin that later morphed into a written language; remaining texts suggest it included loan words from the comic strip "Katzenjammer Kids," among other sources. Some of it found its way into their correspondence in the 1950s and 1960s. They both had a distinctive measured way of speaking their whole lives.

The brothers spent their first year in school in a one-room rural schoolhouse which they did not like much. Thereafter they went to school in town and had some very good and inspiring teachers-a favorite was Grace Jordan, who later was first lady of Idaho and wrote the book Home Below Hell's Canyon. They were bookish from a young age and loathed farm work. When they headed off to the University of Idaho in 1948 (Figure 2), George described freshman year as "one of the happiest of my life, experiencing the liberation of being away from home for the first time, but not too far away for frequent weekend visits, and an atmosphere in which bookishness did not seem weird, but which was still not very competitive intellectually" (Cowgill 1983:2). Warren needed to transfer to pursue a major in classics, so George tagged along with him to Stanford, where he studied physics. There, George briefly audited an introductory anthropology course taught by Felix Keesing, and considered changing majors to anthropology.

After graduating from Stanford, the brothers spent the summer of 1952 on a Smithsonian Institution excavation at Jamestown, North Dakota (Figure 3) George described that experience as "formative in some way, but still not decisive" with respect to his move from physics to anthropology (Cowgill 1983:3). Warren headed to Yale for doctoral study in historical linguistics. George was accepted into Yale's physics program, but, without financial aid, he opted to go instead to Iowa State University, where he was given a teaching assistantship. George continued to read books in anthropology and dabbled in archaeology on weekends; he was growing tired of physics. He then decided to attend graduate school in archaeology at the University of Michigan. In preparation, he read some works by Leslie White, the influential Michigan anthropologist. George was "horrified by his simple-mindedness and dogmatic assertions" (Cowgill 2008a:167). He had reservations about living in Ann Arbor, and said "White's style was one that I associated with the worst kind of small town narrowness and bigotry" (Cowgill 1983:5).

So, instead of attending Michigan, George headed for the University of Chicago to study with Robert McC. Adams. George described his thoughts about anthropology after studying physics: "I thought it was terribly easy after physics and you don't have to be all that bright to do well as an anthropologist-physics was vastly more challenging" (Cowgill 2013a:188). Adams' comparative approach to early states appealed to George, and this was a lasting interest of his. Although interested in working with Adams in Iraq, he turned down the opportunity because his wife, Ursula Moser Cowgill, "didn't want to live in an Islamic country" (Cowgill 2008a:168). Of the various world areas with early states, Mesoamerica seemed to be the best choice. After a fieldwork experience in northwest Mexico with J. Charles Kelley and Carroll Riley, he decided he needed to pursue a Ph.D. in a program with an established Mesoamerican focus, so he transferred to Harvard. 


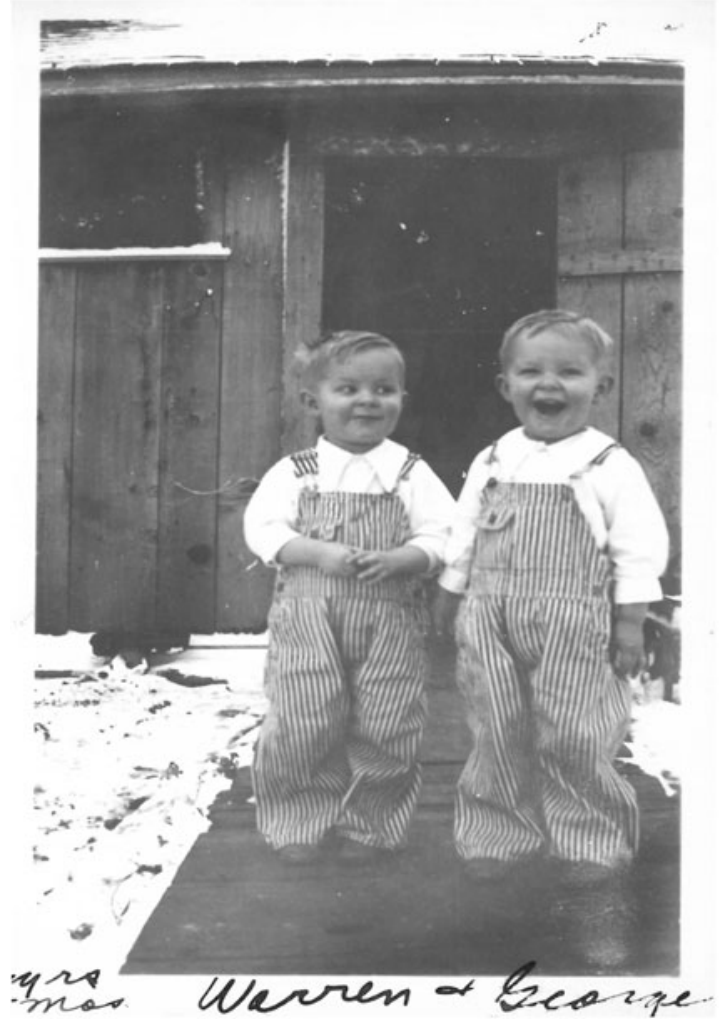

Figure 1. Twins Warren C. and George L. Cowgill at two years, four months of age, March or April 1932. Photograph by their mother, Ruby Smith Cowgill.

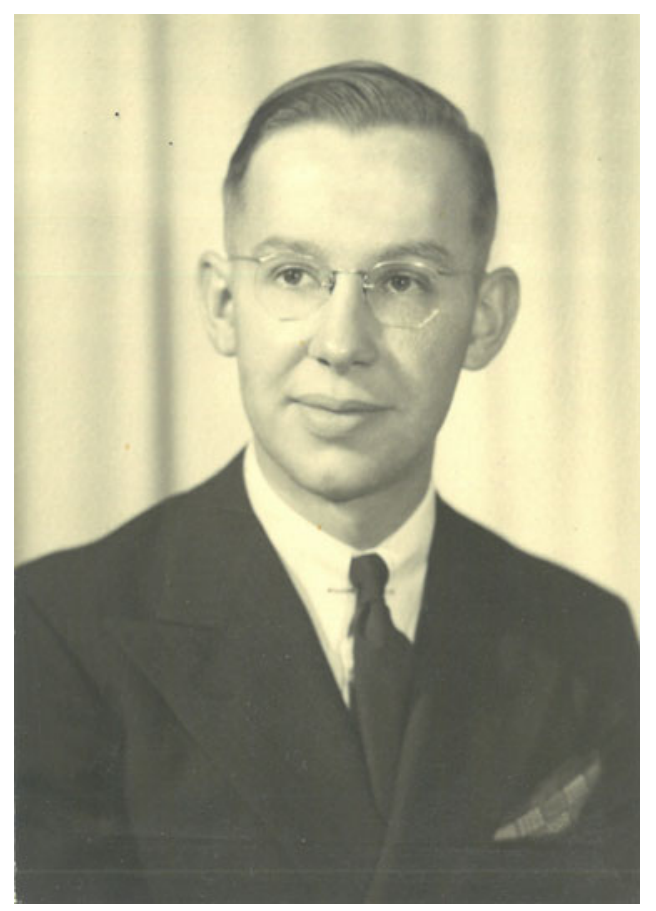

Figure 2. George Cowgill, Grangeville, Idaho High School graduation photo, 1948. Photograph by Shira Studio.

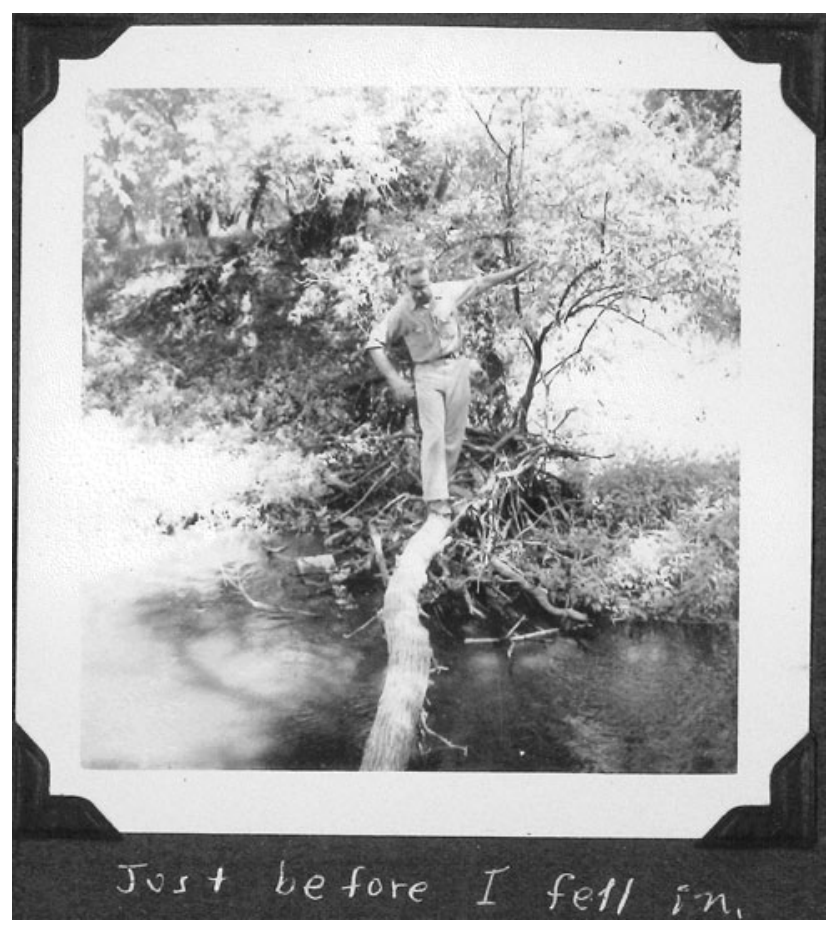

Figure 3. "Just before I fell in. There was a log across the James River, so people spent their lunch-time (sic) on it." George Cowgill, during excavations at Jamestown, North Dakota, summer 1952. Photographer unknown.

The move from the University of Chicago to Harvard University was hard for George. He would later recall, "I have to say that I found Harvard quite a letdown compared to Chicago. Chicago had seemed to be a place of ferment and excitement. Harvard just seemed dead by comparison. Even in the mid twentieth century it seemed like it was still the nineteenth century" (Cowgill 2013a: 189). George got involved in Maya archaeology under Gordon R. Willey at Harvard. He would say, "Willey and I never quarreled, but we just weren't on the same wavelength, and I could get no inspiration from him" (Cowgill 2008a:168).

George and Ursula headed to Guatemala in 1958 for a year of fieldwork at Postclassic sites in the Peten region, during which George suffered a bout of hepatitis A; they returned to Boston in early 1960. After "several troubled months, living on little and worrying about a job" (Cowgill 2008a:169), he received a job offer from the newly formed Department of Anthropology at Brandeis University. He started teaching as an Instructor in fall of 1960 and would remain at Brandeis until 1990. In 1962 he and Ursula divorced, and George was promoted to Assistant Professor. His Ph.D. was awarded in 1963, with a dissertation titled Postclassic Period Culture in the Vicinity of Flores, Petén, Guatemala (Cowgill 1963). He would draw on his thesis to write a review article on the Maya collapse the following year (Figure 4; Cowgill 1964a).

He found Brandeis "exciting and full of promise" (Cowgill 2008a:169), particularly when prominent sociocultural anthropologists Kathleen Gough and David Aberle were hired in 1962. But this couple resigned in 1963 after a public dispute with Brandeis President Abraham Sachar over their protests of the American blockade of Cuba during the Cuban Missile Crisis. The early 1960s was a difficult time for George. For most of this period, he was the only archaeologist at Brandeis, with a heavy teaching 


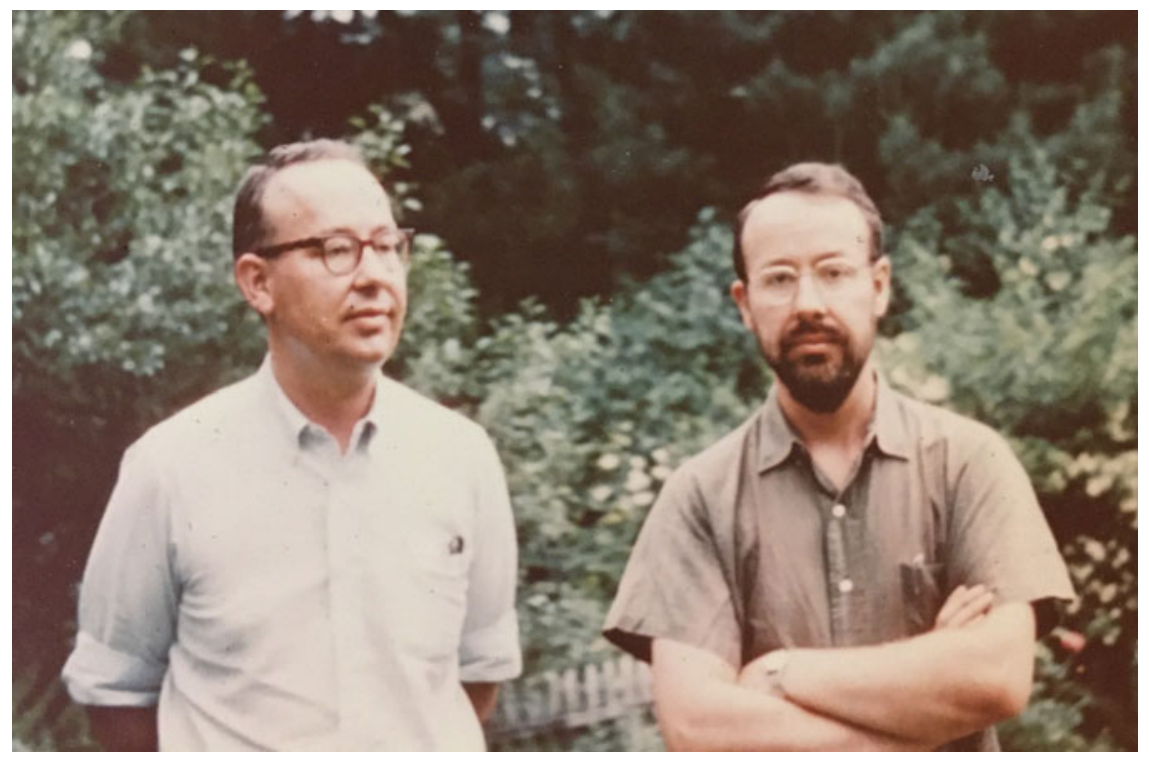

Figure 4. George (left) and Warren (right) Cowgill, Hamden, Connecticut, 1966. Photograph by Sheila A. Cowgill.

load that included physical anthropology. Things improved with the addition of a second archaeologist—Andeanist Craig Morris—and a physical anthropologist to the Department of Anthropology.

In 1964, René Millon invited George to join the Teotihuacan Mapping Project (TMP), beginning an affiliation that turned into the major research focus of George's life. They had first met at the 1958 American Anthropological Association meeting. Many of his contributions in quantitative archaeology were written in the late 1960s and 1970s with data from the TMP. For his first two decades at Brandeis, George retained an affiliation with Harvard, teaching an occasional graduate quantitative seminar there (and also at the Massachusetts Institute of Technology; MIT), and continued to use the Harvard computing center when necessary. Mike Smith recalls running cluster analyses at Harvard using George's account while an undergraduate at Brandeis because the Brandeis computer could not run the required programs.

George married psychologist Cynthia Wild in 1970. He described this as a happy marriage, but Cynthia died of diabetes in 1978. George was discouraged by the lack of support for archaeology at Brandeis; after his twin died in New Haven in 1985 and later a long-term relationship ended, there was little appeal to staying on the east coast, which he had never taken to. He responded enthusiastically to an offer to move to Arizona State University (ASU). Arriving in 1990, he was "instantly provided with an infrastructure [he] hadn't even dreamed of at Brandeis, with stimulating and very congenial colleagues and throngs of good graduate students" (Cowgill 2008a:169).

When Keith Kintigh first approached George about a possible hire at ASU in a conversation during a bus excursion to Etowah (during the 1989 meetings of the Society for American Archaeology; SAA), George remarked that one attraction was that he'd have no trouble wearing Birkenstocks year-round in Tempe-it got sort of cold when there was snow on the ground at Brandeis. George's ASU years, as described in his published autobiography, rescued him and renewed his enthusiasm, both professional and personal (Cowgill 2008a). An ASU graduate student once described George's years at the Tempe campus as "the Camelot years," a particularly rich decade and a half with a large, enthusiastic, talented, and sociable body of graduate students and faculty in archaeology. George taught in the graduate program, with quantitative courses and seminars focused on Mesoamerica or ancient states. Widely read and blessed with an ability to recall abundant information, he could bring copious comparative observations-with special emphasis on ancient Rome- to the classroom, along with deep insights and off-the-cuff analyses. For the graduate students on whose committees he served, he contributed a critical acumen and his hallmark wit. George chaired, cochaired, or was a member of more theses and dissertations in his decade and a half at ASU than in his 30 years at Brandeis.

Throughout his career, George got grants (from funding agencies that included the National Science Foundation (NSF), Wenner-Gren Foundation for Anthropological Research, National Endowment for the Humanities, and the National Geographic Society) to study and preserve collections and data from the TMP and later the results of excavations at the Feathered Serpent Pyramid (Figure 5). Initially these were for computer analyses, but later focused on preserving data and establishing a permanent storage and research facility for field collections and records. His early emphasis on computer-based quantitative and spatial analyses and sampling is reflected in 12 of his first 13 articles, but his articles shifted to topics more directly connected with Teotihuacan at about the time he moved to ASU. Two years before that, he began a cooperative project at the Feathered Serpent Pyramid with Rubén Cabrera Castro. Six later grants continued research on the pyramid excavations. The focus of his research on Teotihuacan continued, accompanied by contributions on broader topics: method and theory beyond the "New Archaeology," rationality and agency, materiality, urbanism, and migration. A reflection of his passion for Teotihuacan was the book Ancient Teotihuacan, published by Cambridge Press in 2015; it remains the definitive English-language book on the site.

\section{CONTRIBUTIONS TO TEOTIHUACAN RESEARCH AND BEYOND}

George Cowgill joined Millon's team on the TMP in 1964. His major contributions were in: (1) helping Millon assemble the 
archaeological map of the ancient city, (2) supervising the artifact collections in Mexico, and (3) curating and analyzing quantitative data derived from the map and the artifacts. George worked closely with Millon and Bruce Drewitt to produce the monumental map of Teotihuacan. Requiring integration of copious field records and endless checking of details, the map was published in 1973 as an oversized book. It consisted of 147 separate map-sheets, one for each of the 500-m TMP grid squares, with plastic overlays showing archaeological interpretations of ancient architecture. Millon et al. (1973) is still one of the most detailed descriptive records ever assembled for an ancient city; George's own copy spent little time on the bookshelf and was ragged and worn (it still sees active service in Smith's lab at ASU).

George sometimes went out with field crews to inspect sites, but he was more at home in the lab in what was then the relatively tranquil town of San Juan Teotihuacan. He helped design procedures to manage collections and worked to maintain year-to-year control over artifact-collection protocols and analyses. The massive artifact collections from the TMP - particularly the systematic collections from the entire surface of the site-were initially stored in a cramped, dark, rented space in San Juan Teotihuacan. Recognizing the need for a larger and better storage/analysis facility, George worked with Susan Toby Evans in the 1980s to purchase a property in San Juan and construct a storage and research facility with funding from the National Science Foundation. One of the conditions of the grant was that this facility accept collections from other U.S. projects. The main storage space of the lab (the "bodega grande") quickly filled up, and a second story was added in 2001, using additional National Science Foundation funds. The lab became even more of a hub for artifact analysis, as well as a base for excavation projects at Teotihuacan; countless archaeologists and students from all over the world have worked there. When George moved to ASU in 1990, the ownership of the lab moved with him.
The ASU lab ("el Mapping" to many in Mexico, but formally the Arizona State University Teotihuacan Research Laboratory) occupied much of George's attention for many years. He supported it, at first to house and analyze collections from the TMP and later to serve as headquarters of projects, collections, and analyses for other Teotihuacan and central Mexico researchers. He was keen on advancing new studies on Teotihuacan-related themes, and encouraged students to study lab collections (Figure 6). He obtained funds from NSF and ASU to support the lab, but often also contributed personal funds to its upkeep. After retiring from ASU, George set up an endowment to support the lab, and a substantial bequest was made from his estate. He facilitated research projects underlying approximately 30 Licenciatura and Master's theses and doctoral dissertations that addressed ceramics, settlement, social variability, and ritual, political, and socioeconomic aspects of ancient Teotihuacan society. Many foreign and Mexican graduate and undergraduate students got their start in Mesoamerican studies thanks to opportunities at the lab, George's connections, through field projects at the city or in the surrounding region, or through analyses of TMP artifacts.

George enjoyed working with pottery (Figure 7). Early in the TMP, James Bennyhoff and Millon (1969) drafted a monograph on Teotihuacan ceramics and chronology. When Bennyhoff left the TMP in the late 1960s, this project was dropped. Evelyn C. Rattray $(1973,2001)$ took over as head ceramicist of the project, and developed a distinctive descriptive account of Teotihuacan ceramics aimed primarily at tracking chronological variation. George became more involved in ceramic analysis over the years, increasingly supervising tabulation work actually carried out by Pedro Baños and Zeferino Ortega, local men whose decades of work in archaeology went back to the earliest days of TMP fieldwork. Trained by Rattray and George and highly knowledgeable in their own right, Baños and Ortega were honored by George and Millon on the occasion of their retirement from lab employment in 2006 (Figure 8).

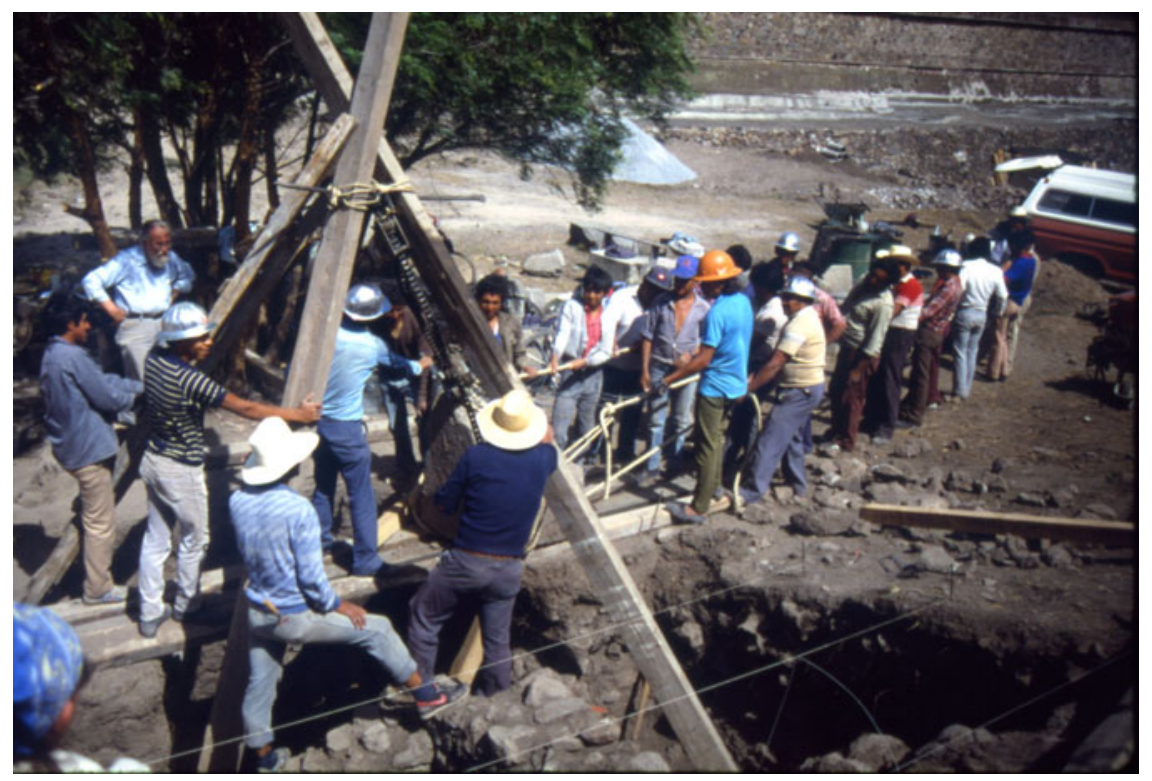

Figure 5. George Cowgill (under tree) at excavations behind the Feathered Serpent Pyramid, July 3, 1989. The workers and archaeologists are extracting from a collapse deposit one of the large sculpted heads that decorated the back of the pyramid. Photograph by Saburo Sugiyama, property of the Proyecto Templo de Quetzalcoatl 1988-1989, courtesy of Rubén Cabrera Castro and Saburo Sugiyama. 


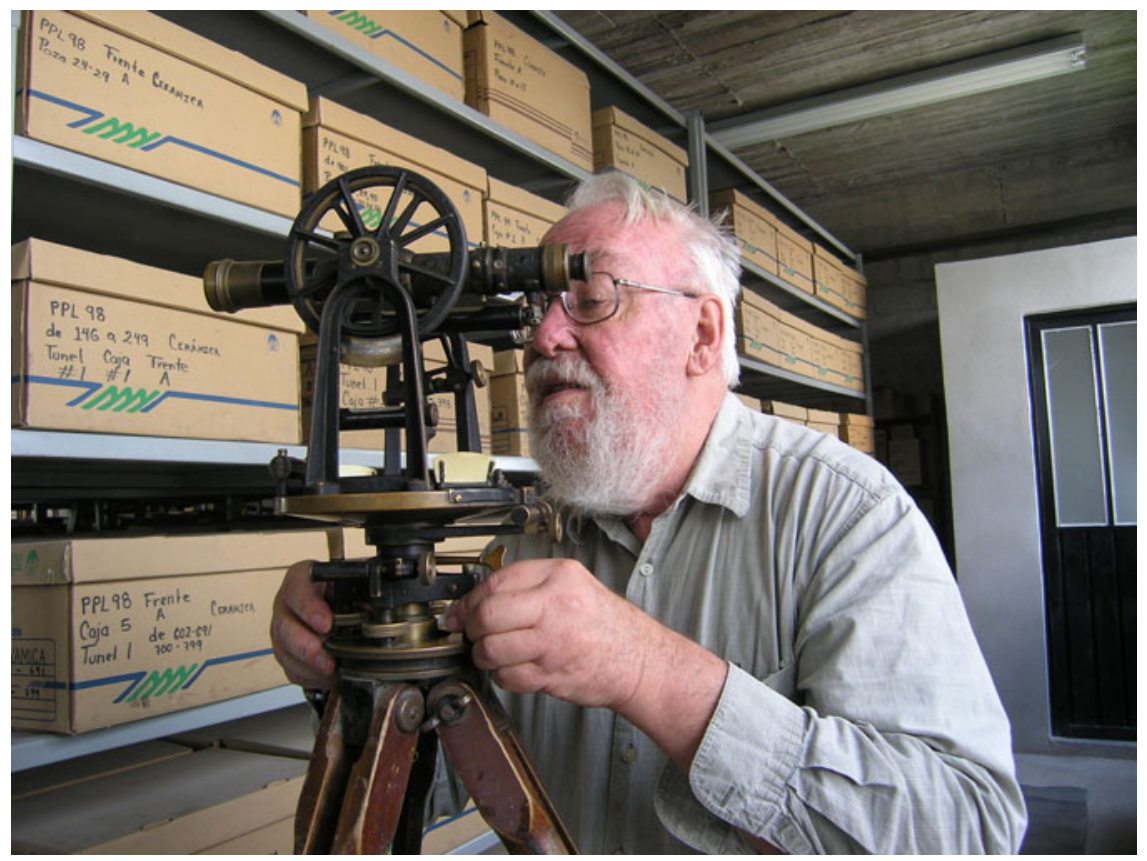

Figure 6. George Cowgill showing students how to work an old theodolite in the Arizona State University Teotihuacan Laboratory, August 2004. Photograph by Sarah Clayton.

As a leading expert in Teotihuacan ceramics, George recognized a need for building on Rattray's work, and he was a strong advocate for further research on Teotihuacan pottery. At some point, George began work on a descriptive account of Teotihuacan ceramics and

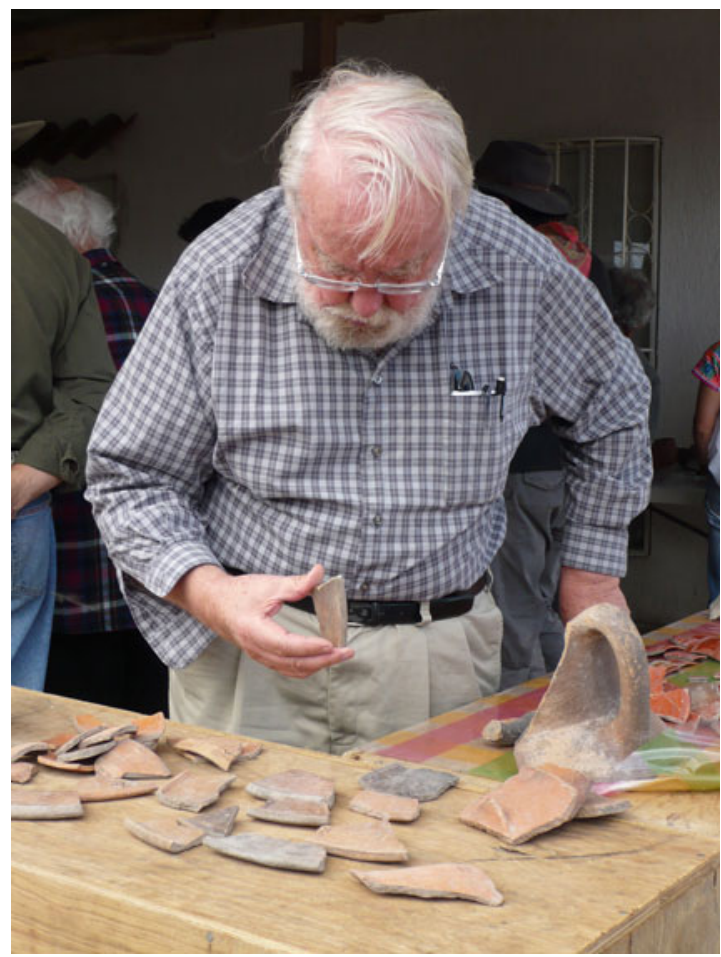

Figure 7. George Cowgill examining pottery at Tecamac I, a salt-making site north of Ecatepec, Basin of Mexico, September 2007. Photograph by Oralia Cabrera. chronology, but didn't complete it: it survives as an unpublished manuscript from 2006 (Cowgill 2006a). He worried that detailed knowledge about the local ceramics was not being passed down to many younger archaeologists, and he repeatedly stressed the need for ongoing research that could lead to corrections and refinements in Teotihuacan pottery systematics. In line with these concerns, George collaborated with Deborah Nichols in 2008 to organize an informal but intense hands-on ceramic workshop in which students from various projects working out of the Teotihuacan Lab participated.

Reflecting his personal predilections for numerical and formal analysis, George was instrumental in "computerizing" the vast amount of data that, beginning around 1962, was generated by ongoing TMP research. Some planning for a project database evidently predated his involvement, but database construction began in earnest in 1965, and an early prototype was ready for pilot analyses by 1966 . For many years, a mainframe (VAX) computer housed both TMP data and analytical tools. The basic data management, statistical analysis, and mapping tools were cumbersome by modern standards, but George (and later, his students) used them energetically in early explorations of urban land use at Teotihuacan. They made isopleth maps, for example, by hand-plotting contours on printed maps, the contours distilled from digital printout summaries created by custom software (Cowgill 1974).

In the late 1980s, George codirected the Proyecto Templo de Quetzalcoatl with Cabrera Castro (INAH), assisted by his then-doctoral student Saburo Sugiyama and other students from institutions in Mexico and the United States. In part because earlier excavations uncovered evidence of sacrificial burials in its immediate vicinity, George and colleagues excavated and tunneled into this pyramid, one of the most striking monuments of the civic-ceremonial core of Teotihuacan. This was one of the earliest projects to bring to light evidence of foundation rituals of civic-ceremonial architecture featuring mass-sacrificial practices and overt warfare symbolism 


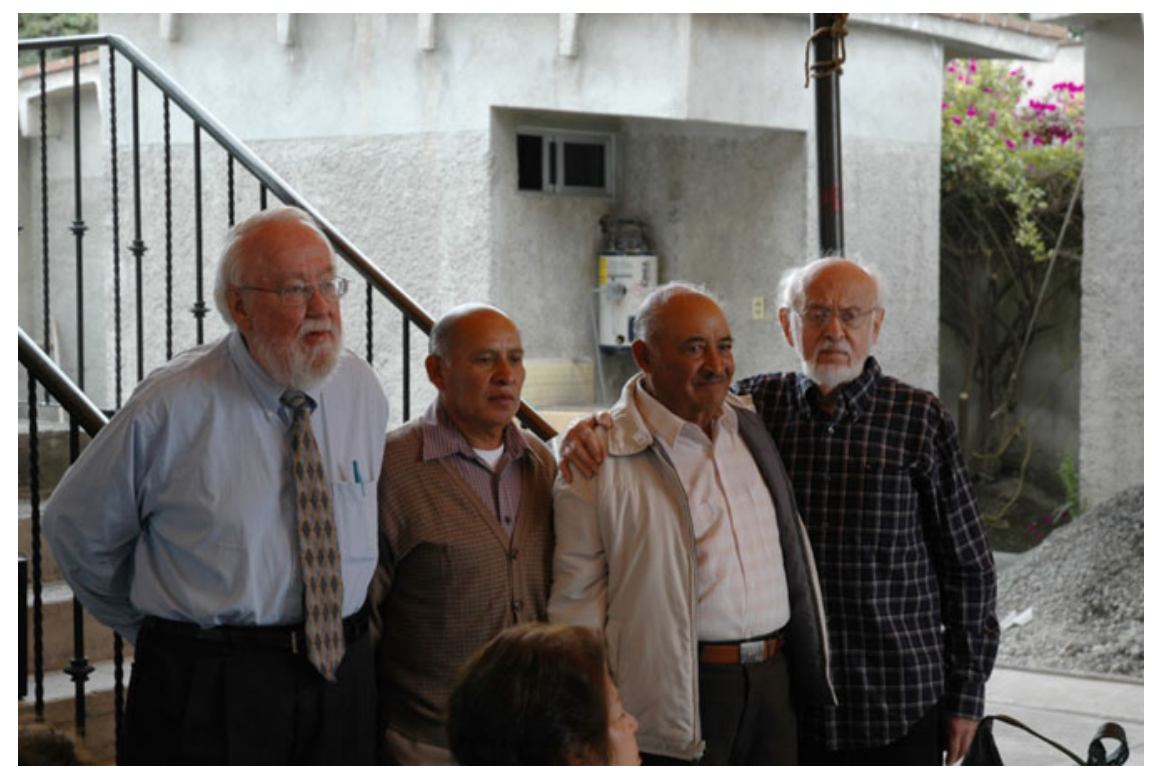

Figure 8. Ceremony at the Teotihuacan Research Laboratory in honor of Teotihuacan Mapping Project assistants, Pedro Baños Céspedes and Zeferino Ortega Mendoza, June 30, 2006. From left: George Cowgill, Zeferino Ortega, Pedro Baños, and René Millon. Photograph by Oralia Cabrera.

(Cabrera Castro et al. 1990, 1991). It changed perceptions about Teotihuacan society, bringing human sacrifice to the center of the discussion. This project launched the career of Sugiyama (2005), who has gone on to become the premier foreign archaeologist excavating at Teotihuacan.

George's contributions to Teotihuacan research were substantial and very diverse, a legacy that goes beyond the scope of this article. He was a frequent discussant at symposia on Teotihuacan. He took over Millon's role as the major English-language synthesizer of research and findings at the city. George's review articles still provide a good introduction to research at the site by Mexican and foreign archaeologists (Cowgill 1992b, 1997, 2007, 2008b).

George encouraged his students to read widely about early cities and states around the world. He published a number of theoretical and comparative papers that contribute to the larger literature on early states; these include comparative analyses of early cities and urbanism (Cowgill 2000, 2003a, 2004a), domestic contexts in cities (Cowgill 2002a), and the notion of societal collapse (Cowgill 1964a, 1988, 2012). Many of his papers on Teotihuacan linked research on that city to broader theoretical and comparative themes, including state ideology (Cowgill 1992b, 2003b), social classes and inequality (Cowgill 1992a), and migration (Cowgill 2013b, 2015). Other areas of research to which George contributed include ancient population growth (Cowgill 1975a), archaeological theory (Cowgill 1993, 2004b), and quantitative archaeology. George mused in an unpublished reflection from 1983 that he probably would have published more by that point if he had been happier with his personal and professional circumstances, but this early selfanalysis did not anticipate the impact of later work that led to his national and international reputation.

\section{CONTRIBUTIONS TO QUANTITATIVE ARCHAEOLOGY}

Throughout his career, George was an international leader in the application of mathematical and statistical methods-what he preferred calling formal approaches - to the analysis of archaeological data (Cowgill 1986, 1989b). His contributions to quantitative archaeology began in the early days of the TMP, and they included both analyses of Teotihuacan data and more general methodological works. Widely admired as an authority in this domain, George became American Antiquity's first Consulting Editor for Mathematics and Statistics in 1981.

George regarded informed application of formal methods as essential to making secure knowledge claims in archaeology. He made substantial contributions to a wide range of quantitative topics including sampling (Cowgill 1964b, 1970, 1975b, 1994), seriation (Cowgill 1968, 1972), classification (Cowgill 1968, 1982, 1990a), and database structure (Cowgill 1967, 2006b). With his distinctive style and dry wit, George brought mathematical and statistical principles to bear on problems as diverse as demography (Cowgill 1975a), archaeological survey (Cowgill 1990b), diversity (Cowgill 1989a), and spatial analysis (Cowgill et al. 1984).

George emphasized two general ideas about quantitative work. One was that statistical methods are not a way to dodge the difficult and often messy work of thinking about archaeological data in anthropologically and historically informed ways. Another was that statistical approaches are often most useful for clarifying the nature of ambiguity in our data-helping us identify a range of plausible outcomes rather than pointing to a single, clear (and perhaps favored!) one (Figure 9).

George Cowgill was a superb and generous teacher of quantitative and formal methods at Brandeis, Harvard, MIT, and ASU. In his teaching, he insisted that students gain a real understanding of the operation of a few key probability distributions because he saw that as necessary for thinking clearly about archaeological data. While he certainly attended to the mechanics of applying various methods, George insisted that students understand how to properly describe and interpret quantitative results in the context of a research question. Similarly, George had a very practical respect for exploratory data analysis and statistical graphics. These topics figured prominently in his teaching and in some of his 


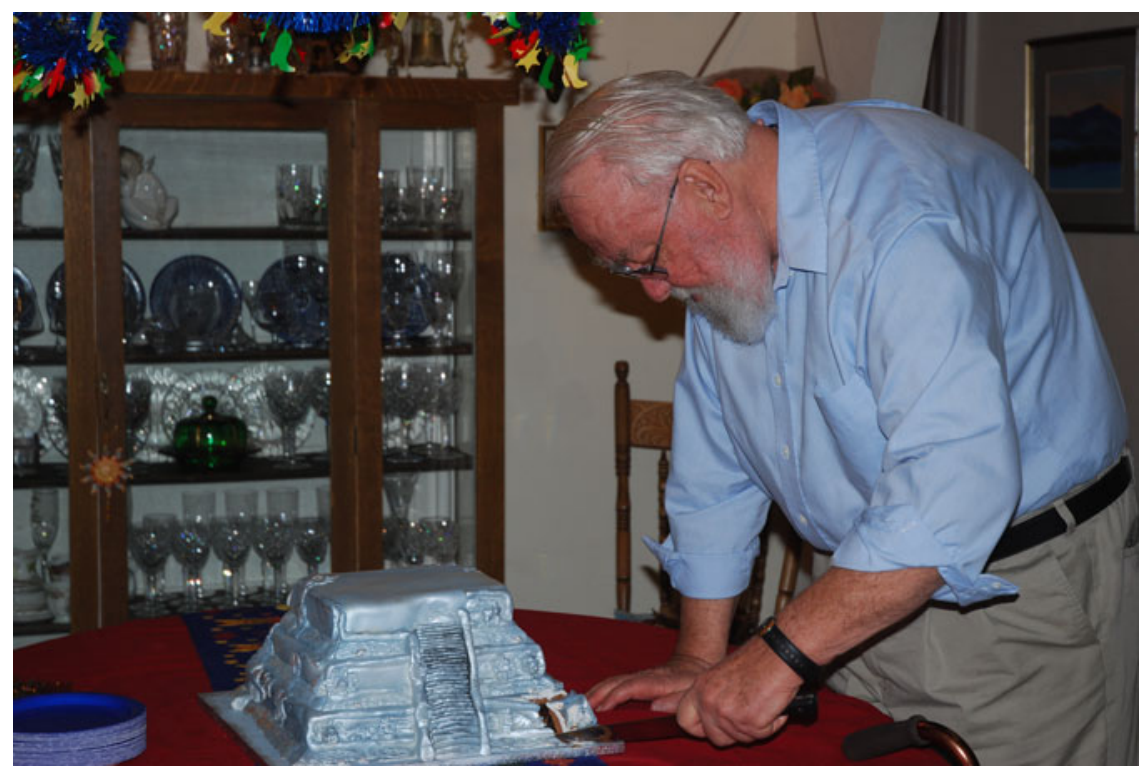

Figure 9. George Cowgill cutting the cake for his 80th birthday party on December 12, 2009 (a week before his actual birthdate). The cake, made by Alanna Ossa, was in the form of the Feathered Serpent Pyramid. Photograph by Brenda Shears.

publications. Obvious spatial examples include high-informationcontent maps of Teotihuacan artifact distributions in two book chapters (Cowgill 1974; Cowgill et al. 1984). Although these graphics often require a little extra thought and study, they are useful for descriptive purposes, and for generating new ideas and testable hypotheses about complex data. Maps and graphics aside, George's attraction to exploratory data analysis approaches was reflected in his early use and promotion of multivariate statistical procedures in anthropology and archaeology.

Several of George's papers were clearly intended as constructive correctives to common statistical (mal)practice. Every archaeologist should firmly embrace George's elegant and highly readable 400-word essay, "Things to Remember about Statistics (Whatever Else You Forget)" (Cowgill 2005). While significantly more effort is required to understand "The Trouble with Significance Tests and What We Can Do About It" (Cowgill 1977), it is a crucial contribution that is every bit as relevant today as it was 43 years ago. That paper cogently explains why estimation approaches are better suited to our problems than significance testing, and urges us to think hard about what different parameter intervals might mean in light of known cultural behavior or readings of history. If you have absorbed the arguments in that article, you can never again take 0.05 as a magic threshold and go on to assume that statistical significance automatically establishes behavioral or social significance. This paper also reflects the strong attraction that George felt toward Bayesian methods (Cowgill 1989b, $1994,2002 b)$, both as a philosophical approach to knowledge acquisition, and as a basis for statistical practice.

George's abiding concern for rigor in analysis and clarity in argumentation was unfailingly modeled in his own writing. His arguments are powerful and effective, in part because they are always informed by the practical realities of dealing with archaeological data. Even when addressing difficult topics, he was able to communicate effectively with a broad professional audience. Although George's papers incorporating formal approaches to archaeology span more than 50 years, most are still well worth reading today. It would be difficult to overestimate the impacts of George's writing and his teaching on the current state of quantitative archaeology.

\section{THE MAN AND HIS LEGACY}

George's excellence as a scholar was recognized particularly in his appointments to editorial boards and his receipt-jointly with Millon-of the American Anthropological Association's A.V. Kidder Award for Eminence in American Archaeology in 2004. Earlier he was recognized for his contributions in quantitative analysis with a SAA Excellence in Archaeological Analysis award in 2001. In 1992-1993 he was a Fellow at the Center for Advanced Study in the Behavioral Sciences at Stanford University. Still earlier, he received the Pomerance Award for Scientific Contributions to Archaeology from the Archaeological Institute of America, 1987.

In October 2011, in recognition of decades of research dedicated to the ancient city, the INAH held the "Fifth Mesa Redonda of Teotihuacan" in George's honor. The conference, "Teotihuacan. Investigaciones Recientes, Centro y Periferia: Homenaje a George L. Cowgill," was attended by large numbers of colleagues from Mexico, the United States, and other countries. George delivered the keynote address on the first day, and INAH produced a video featuring interviews with George and various friends, students, and colleagues (Figure 10). This was a rare honor for a foreign archaeologist.

Perhaps surprising to those who knew George only from his formal presentations, he was a "party animal" and seldom missed social events in his department or at national meetings. Archaeology was a huge slice of his life, but there was more. Upon arriving in Tempe, he bought a new sedan-it was in that car that he travelled to Teotihuacan the next summer with the Sugiyama family. Warren Barbour was eagerly awaiting their arrival in San Juan with a camera, ready to capture George's expression after a long journey with three very young children. For years after moving to Arizona, he drove up to Idaho in summer to visit 


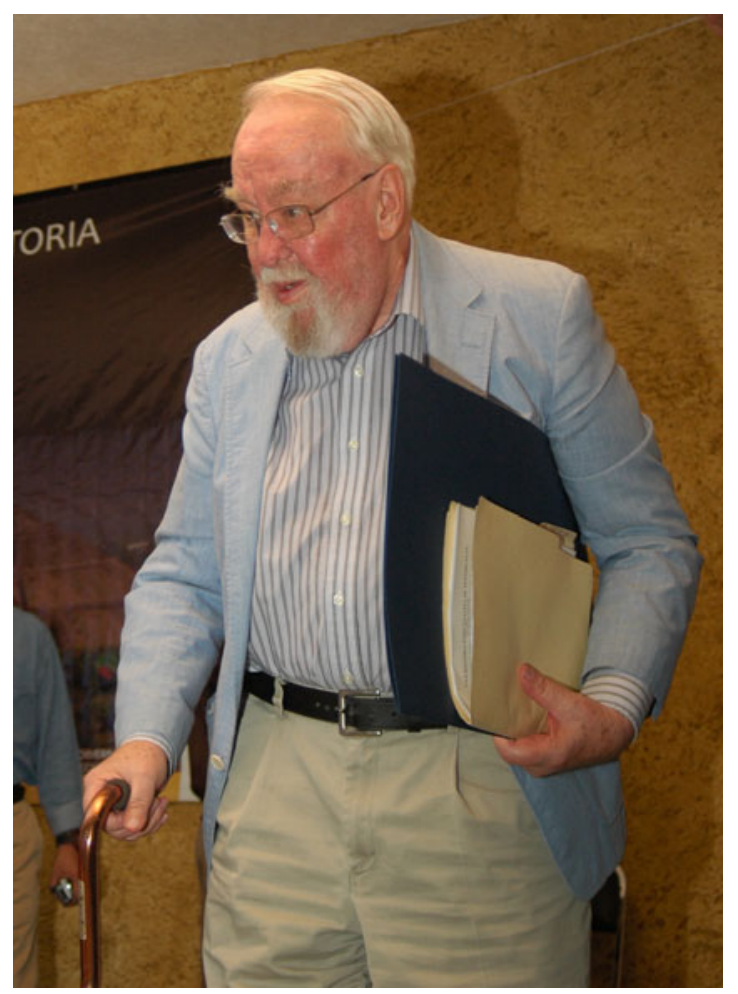

Figure 10. George Cowgill just after delivering his keynote address at the Mesa Redonda de Teotihuacan symposium held in his honor, October 23, 2011. Photograph courtesy of Instituto Nacional de Antropología e Historia, provided by Sandra Riego.

relatives and the farm where he grew up. Vehicle maintenance was not his strong suit, and friends often had to insist on a trip to the

\section{REFERENCES}

Bennyhoff, James A., and René Millon

1969 Untitled Report on Teotihuacan Ceramics. Files of the Teotihuacan Mapping Project, Arizona State University, Tempe.

Cabrera Castro, Rubén, George L. Cowgill, and Saburo Sugiyama

1990 El Proyecto Templo de Quetzalcoatl y la práctica a gran escala del sacrificio humano. In La epoca clásica: Nuevos hallazgos, nuevas ideas, edited by A. Cardós de Méndez, pp. 123-146. Instituto Nacional de Antropología e Historia, Mexico City.

Cabrera Castro, Rubén, Saburo Sugiyama, and George L. Cowgill

1991 The Templo de Quetzalcoatl Project at Teotihuacan: A Preliminary Report. Ancient Mesoamerica 2:77-92.

Cowgill, George L.

1963 Postclassic Period Culture in the Vicinity of Flores, Petén, Guatemala. Unpublished Ph.D. dissertation, Department of Anthropology, Harvard University, Cambridge.

1964a The End of Classic Maya Culture: A Review of Recent Evidence. Southwestern Journal of Anthropology 20:145-159.

$1964 \mathrm{~b}$ The Selection of Samples from Large Sherd Collections. American Antiquity 29:467-473.

1967 Computers and Prehistoric Archaeology: Readings and Perspectives. In Computers in Humanistic Research, edited by Edmund A. Bowles, pp. 47-56. Prentice-Hall, Englewood Cliffs.

1968 Archaeological Applications of Factor, Cluster, and Proximity Analysis. American Antiquity 33:367-375.

1970 Some Sampling and Reliability Problems in Archaeology. In Archéologie et Calculaterus: Problèmes semiologiques et mathematiques, edited by Jean-Claude Gardin, pp. 161-175. Editions du Centre National de la Récherche Scientifique, Paris. mechanic. Summers also routinely involved a trip by air to the laboratory at San Juan Teotihuacan. While the ASU lab was primarily a place of research, it also served as a hub where he interacted and socialized with others engaged in research in central Mexico.

In the wider profession, George's influence stemmed from his carefully expressed and highly informed research papers. But, as in the lives of many scholars, his influence also spread via the smaller settings of seminars, committees, parties, and conversations at meetings. Each influenced the course of research in archaeology. Often kind to others behind the scenes, he was also irascible about professional blather and prone to rank others according to his appreciation of their intelligence (though he accepted his pet cats unconditionally). Colleagues and students never knew when George's wit would enliven a moment. Arleyn Simon cochaired a doctoral committee with him and asked if he needed a pen to sign the approval form. He got a mischievous smile as he reached for his shirt pocket, pulled out a black pen, and asked, "would Wild Bill Hickok go to a gun fight without his weapon?" He then signed the form with panache. Arleyn's telling of this anecdote brought a round of laughter echoing the original moment at a memorial service for George on the ASU campus.

Unbeknownst to many, George loved music and had a good collection of classical and folk music. He was fond of Celtic music, Portuguese fados, and sones from the Huastec region of Mexico. George enjoyed participating in contra dances, and was sometimes joined by his students. George also loved to eat, especially Indian and Mexican food. Despite a very healthy appetite, George was not a cook, but encouraged culinary encounters with graduate students who were occasional guests in his home.

We close with a quote from Dorothy Hosler, a colleague and friend of George's: "I don't think I ever have learned as much about how to think about archaeological data as I did from George — no junk terminology, no junk science. What a privilege to have studied with him."

1972 Models, Methods and Techniques for Seriation. In Models in Archaeology, edited by David Clarke, pp. 381-424. Methuen, London.

1974 Quantitative Studies of Urbanization at Teotihuacan. In Mesoamerican Archaeology: New Approaches, edited by Norman Hammond, pp. 363-396. University of Texas Press, Austin.

1975a On Causes and Consequences of Ancient and Modern Population Changes. American Anthropologist 77:505-525.

1975b A Selection of Samplers: Comments on Archaeo-statistics. In Sampling in Archaeology, edited by James W. Mueller, pp. 258-274. University of Arizona Press, Tucson.

1977 The Trouble with Significance Tests and What We Can Do about It. American Antiquity 42:350-368.

1982 Clusters of Objects and Associations Between Variables: Two Approaches to Archaeologial Classification. In Essays on Archaeological Typology, edited by Robert Whallon and James A. Brown, pp. 30-55. Center for American Archaeology Press, Evanston.

1983 Unpublished autobiographical notes. Archives of the Teotihuacan Mapping Project, Arizona State Universitiy, Tempe.

1986 Archaeological Applications of Mathematical and Formal Methods. In American Archaeology, Past and Future, edited by David J. Meltzer, Don D. Fowler, and Jeremy A. Sabloff, pp. 369-393. Smithsonian Institution Press, Washington, DC.

1988 Onward and Upward with Collapse. In The Collapse of Ancient States and Civilizations, edited by Norman Yoffee and George L. Cowgill, pp. 244-276. University of Arizona Press, Tucson.

1989a The Concept of Diversity in Archaeological Theory. In Quantifying Diversity in Archaeology, edited by Robert D. Leonard and George T. Jones, pp. 131-141. Cambridge University Press, New York. 
1989b Formal Approaches in Archaeology. In Archaeological Thought in America, edited by C.C. Lamberg-Karlovsky, pp. 74-88. Cambridge University Press, New York.

1990a Artifact Classification and Archaeological Purposes. In Mathematics and Information Science in Archaeology: A Flexible Framework, edited by Albert Voorrips, pp. 61-78. HOLOS Verlag, Bonn.

1990b Toward Refining Concepts of Full-Coverage Survey. In The Archaeology of Regions: The Case for Full-Coverage Survey, edited by Suzanne K. Fish and Stephen A. Kowalewski, pp. 249-260. Smithsonian Institution Press, Washington, DC.

1992a Social Differentiation at Teotihuacan. In Mesoamerican Elites: An Archaeological Assessment, edited by Diane Z. Chase and Arlen F. Chase, pp. 206-220. University of Oklahoma Press, Norman.

1992b Toward a Political History of Teotihuacan. In Ideology and Pre-Columbian Civilizations, edited by Arthur A. Demarest and Geoffrey W. Conrad, pp. 87-114. School of American Research Press, Santa Fe.

1993 Distinguished Lecture in Archaeology: Beyond Criticizing New Archaeology. American Anthropologist 95:551-573.

1994 Unknown Bias Is Not a License to Ignore Statistical Theory. In Methods in the Mountains, Vol. 2, edited by Ian Johnson, pp. 7-11. University of Sydney, Department of Prehistoric and Historic Archaeology, Sydney.

1997 State and Society at Teotihuacan, Mexico. Annual Review of Anthropology 26:129-161.

2000 Intentionality and Meaning in the Layout of Teotihuacan, Mexico. Cambridge Archaeological Journal 10: 358-361.

2002a Contextos domésticos en Teotihuacan. In Ideología y política a través de materiales, imágenes y símbolos (Memoria de la Primera Mesa Redonda de Teotihuacan), edited by María Elena Ruiz Gallut, pp. 61-74. Instituto Nacional de Antropología e Historia, Mexico City.

2002b Getting Bayesian Ideas Across to a Wider Audience. Archeolgia e Calculatori 13:191-196.

2003a Some Recent Data and Concepts about Ancient Urbanism. In El urbanismo en Mesoamérica/Urbanism in Mesoamerica, edited by William T. Sanders, Alba Guadalupe Mastache, and Robert H. Cobean, pp. 1-20. Proyecto Urbanismo en Mesoamérica/The Mesoamerican Urbanism Project, Vol. 1. Pennsylvania State University, University Park, and Instituto Nacional de Antropología e Historia, Mexico City.

2003b Teotihuacan: Cosmic Glories and Mundane Needs. In The Social Construction of Ancient Cities, edited by Monica L. Smith, pp. 37-55. Smithsonian Institution Press, Washington, DC.

2004a Origins and Development of Urbanism: Archaeological Approaches. Annual Review of Anthropology 33:525-549.

2004b Thoughts About Rethinking Materiality. In Rethinking Materiality: The Engagement of Mind with the Material World, edited by Elizabeth DeMarrais, Chris Gosden, and Colin Renfrew, pp. 273-280. McDonald Institute Monographs. McDonald Institute for Archaeological Research, Cambridge.
2005 Things to Remember about Statistics (Whatever Else You Forget). The SAA Archaeological Record 5:35.

2006a An Outline of the Ceramics of Teotihuacan, Mexico. Unpublished manuscript, files of the Teotihuacan Mapping Project, Arizona State University, Tempe.

2006b Using Numerous Cases to Extract Valid Information from Noisy Surface Data at Teotihuacan. In Managing Archaeological Data: Essays in Honor of Sylvia W. Gaines, edited by Jeffrey L. Hantman and Rachel Most, pp. 147-154. Anthropological Research Papers, Vol. 57. Arizona State University, Tempe.

2007 The Urban Organization of Teotihuacan, Mexico. In Settlement and Society: Essays Dedicated to Robert McCormick Adams, edited by Elizabeth C. Stone, pp. 261-295. Cotsen Institute of Archaeology, University of California Los Angeles, Los Angeles.

2008a How I Got to Where I Am Now: One Thing After Another, A (Mostly) Linear Narrative. Ancient Mesoamerica 19:165-173.

2008b An Update on Teotihuacan. Antiquity 82: 962-975.

2012 Concepts of Collapse and Regeneration in Human History. In The Oxford Handbook of Mesoamerican Archaeology, edited by Deborah L. Nichols and Christopher Pool, pp. 301-308. Oxford University Press, New York.

2013a Conversations with William L. Rathje and Michael Shanks. In Archaeology in the Making: Conversations through a Discipline, edited by William L. Rathje, Michael Shanks, and Christopher Witmore, pp. 185-203. Routledge, New York.

2013b Possible Migrations and Shifting Identities in the Central Mexican Epiclassic. Ancient Mesoamerica 24:131-149.

2015 The Debated Role of Migration in the Fall of Ancient Teotihuacan in Central Mexico. In Migration and Disruptions: Toward a Unifying Theory of Ancient and Contemporary Migrations, edited by Takeyuki Tsuda and Brenda Baker, pp. 97-122. University Press of Florida, Gainesville.

Cowgill, George L., Jeffrey H. Altschul, and Rebecca S. Sload

1984 Spatial Analysis of Teotihuacan, a Mesoamerican Metropolis. In Intrasite Spatial Analysis in Archaeology, edited by Harold J. Hietala, pp. 154-195. Cambridge University Press, New York.

Millon, René, R. Bruce Drewitt, and George L. Cowgill

1973 Urbanization at Teotihuacan, Mexico, Volume 1: The Teotihuacan Map, Part 2: Maps. University of Texas Press, Austin.

Rattray, Evelyn C.

1973 The Teotihuacan Ceramic Chronology: Early-Tzacualli to Early-Tlamimilolpa Phases. Unpublished Ph.D. dissertation, Department of Anthropology, University of Missouri, Columbia.

2001 Teotihuacan: Cerámica, cronología y tendencias culturales/ Ceramics, Chronology and Cultural Trends. Arqueología de México. Instituto Nacional de Antropología e Historia, Mexico City, and University of Pittsburgh, Pittsburgh.

Sugiyama, Saburo

2005 Human Sacrifice, Militarism, and Rulership: The Symbolism of the Feathered Serpent Pyramid at Teotihuacan, Mexico. Cambridge University Press, New York. 